\title{
Optimization of Civil Engineering Materials Experiment Teaching Design
}

\author{
Zhou Yanhua \\ Jiangxi University of Technology,Nanchang Key Laboratory of material and structure detection
}

\begin{abstract}
Civil Engineering Materials is an important professional basic course, which is arranged for sophomore. The second year for college students is the period changing from basis to professional, the bridge to contact their major. Civil engineering material teaching includes classroom instruction and experiment. Classroom teaching focuses on material properties, standards, applications and preparation methods. But there is a wide range of civil engineering materials, from inorganic to organic, from metal to non-metal. And the components and properties of various materials vary widely. The content of classroom teaching is difficult to connect with a main line, spanning more. To master teaching content and lay foundation for the future engineering applications, the paper discusses the common problems in current experimental teaching, guide with constructivist learning theory, from four aspects of teaching objectives, teaching objects, teaching content, teaching process experimental for optimizing civil engineering teaching design, forming a new civil engineering materials experimental teaching design mode and take effect analysis.
\end{abstract}

Keywords-constructivism; civil engineering materials; experiment teaching; teaching reform

\section{I.INTRODUCTION}

The graduated students of Civil Engineering Major will no longer confined to the building structure engineering field, but face a number of professional engineering fields of road transport, highways and railways, ports, dams, underground tunnels, bridges, airports and other professional engineering fields. A large number of graduates flock to construction companies of various sectors, and some go to engineering quality inspection sector. According to the existing position and the quality of enrolled students in civil engineering major in the country, the training objectives should emphasize "integrated, technology-based, application-oriented" high-level talents adapting to modern civil engineering construction. At the same time, through innovative quality-oriented education and individualized teaching, and strive to cultivate a small part of the "creative" or "research-based" high-level talents. These high-quality talent is required to have extensive knowledge, strong ability to acquire knowledge, a strong sense of innovation and competition and strong ability of engineering practice.

Civil engineering material covers a wide range of contents, including inorganic non-metallic materials, metal materials, organic polymer materials, so the content is complicated. Due to the limited credit hours, theory course is difficult to complete, experimental courses are often compressed, particularly prominent in the colleges with poorer experimental resources, and some schools even cancel the experimental course. Moreover, the experimental course also emphasizes on validation experiments, lacking of comprehensive and designed experiments and optional experiments against different majors, obviously insufficient for cultivating operational ability, creative thinking and innovation. It is a very urgent task to improve the teaching quality of civil engineering material experiment course to cultivate high-quality engineering and technical personnel under the conditions of less credit hours, and more teaching contents. The authors put forward the following measures after thinking.

The paper analyzes the existing problems of civil engineering materials experiment course, and propose the reform measures from strengthening laboratory construction, experimental teaching content optimization, strengthening laboratory openness, playing the main role 
of teachers and reform assessment and evaluation mechanism .

\section{II.THE EXISTING PROBLEMS AND ANALYSIS OF EXPERIMENTAL TEACHING OF CIVIL ENGINEERING MATERIALS}

Currently, although the civil engineering major within our college conducts preliminary reform, but still lags behind the development of university reform. For civil engineering materials experiments, the following problems exist.

1. The traditional teaching method taking teacher explaining experiment as the main body, grouping students for validation experiments according to the requirement of the teachers no longer meets the current higher education system taking quality education as the core, focusing on cultivating the creative and scientific research ability.

2. After major integration, the experiment contents in the existing teaching material "Civil Engineering Materials" depend more on experimental theoretical teaching, and the content is single, and almost confirmatory test, especially considering with unevenness for subsequent courses of organic convergence, with less design and comprehensive, experimental research features, so they can not meet the requirements of professional education, affecting the accumulation and coverage of knowledge.

3. Teaching methods are too single, and teachers lack vividness in experiment lessons teaching with repetitive work. It is more difficult to focus the attention of students in class. Therefore it is urgent to introduce multimedia technology assisting teaching.

4. Lacking of scientific and reasonable evaluation for student experiment lessons results the students have less initiative, which is extremely unfavorable for students sense of competition and innovation.
III.OPTIMIZATION OF EXPERIMENTAL TEACHING CONTENT, AND EXPERIMENT TEACHING SYSTEM REFORM

Civil Engineering Materials course aims at more majors and each major must combine with the major features and optimize experimental course content. We made some reforms in teaching, such as the integration of original "sand, stone experiment" and "ordinary concrete workability, strength test",as well as concrete mix ratio design, making it a comprehensive and designed experiment; for the civil engineering major, add "asphalt mixture" optional experiment; for architecture, urban planning major, add "ceramic brick performance" optional experiment; for water supply and drainage engineering, building environment and equipment engineering major, add "plastic pipe performance " optional experiments, and the experimental teaching system after reform is shown in Table 1.

\section{CIVIL ENGINEERING MATERIAL EXPERIMENT TEACHING EFFECT ANALYSIS}

Civil engineering material experiment is detection experiment, to test whether the material technical indicators meet the national standards or design requirements, and determine the material properties based on the analysis and whether the material can be used. In the traditional experimental teaching model, laboratory technicians prepare materials for students and they finish the experimental procedure as instructed by the teachers to complete the predetermined experiment content. So it is an unrealistic and engineering validation experiment, which does not provide analysis for students to determine the conditions and the students lack of learning enthusiasm and initiative that is not conducive to develop students' creative thinking. 
TABLE I. Experiment teaching system of civil engineering materials

\begin{tabular}{|l|l|l|}
\hline Experimental items & Contents & Types \\
\hline $\begin{array}{l}\text { The basic physical properties } \\
\text { experiments of civil engineering } \\
\text { materials }\end{array}$ & $\begin{array}{l}\text { Brick density, apparent density, porosity, water } \\
\text { absorption, water resistance test }\end{array}$ & Confirmatory \\
\hline Wall Material Testing & $\begin{array}{l}\text { Sintered common brick or autoclaved sand-lime } \\
\text { brick anti-flexural strength, compressive strength } \\
\text { test, and measuring the intensity level }\end{array}$ & Confirmatory \\
\hline Cement experiment & $\begin{array}{l}\text { Apparent density, bulk density and screening } \\
\text { experiments of sand; apparent density, bulk } \\
\text { density and screening experiment of stones; } \\
\text { concrete mixing ratio design; concrete mixture } \\
\text { workability, apparent density testing, concrete } \\
\text { strength measurement }\end{array}$ & Integrity \\
\hline masonry mortar & $\begin{array}{l}\text { Mortar workability testing, mortar strength grade } \\
\text { test }\end{array}$ & $\begin{array}{l}\text { Tensile, cold-drawn strengthening, cold-drawn } \\
\text { aging strengthening experiment }\end{array}$ \\
\hline Rebar experiment & $\begin{array}{l}\text { Penetration, ductility, softening point experiment } \\
\text { experiment, application examples of civil } \\
\text { engineering materials }\end{array}$ & Confirmatory \\
\hline Watch experiment video & demonstration \\
\hline
\end{tabular}

In the new instructional design, the experiments on the background of practical engineering, considering a variety of status and parameters of the real-life situation, students access to information, develop experimental program and complete the experimental records, lab reports of practical engineering applications with the help of multimedia and thematic websites and other cognitive tools. Throughout the experiment process, students are always the subject of teaching activities, which inspires and mobilizes the students' enthusiasm and initiative, to improve the ability of independent learning. Through multimedia courseware and demonstration of basic experimental methods of operation, teachers provide students with problem-solving clues, inspiring and inducing students to correct and supplement the errors and problems in the experiment; to organize collaborative learning and put forward the right questions to guide students to think and discuss, to deepen students understanding what they have learned, so as to build up relatively independent conscious thinking and knowledge structure of innovative content system based on mastering the basic knowledge.

\section{V.CONCLUSION}

Experimental teaching is the combining process of abstract thinking and image thinking, imparting knowledge and training skills. To improve the quality of experiment teaching, the key lies in the modern teaching theory and learning theory, teaching design optimization and reform of teaching methods. After years of practice and exploration, new experimental teaching mode of civil engineering materials experiment teaching have made a good experiment teaching effect.

1. The engineering practice ability of students is significantly enhanced the survey shows that: more than $90 \%$ students can master a range of engineering quality testing work such as sampling, self-inspection, inspection, engineering parts point detection; students can effectively control the quality of the material in the construction process according to project requirements, selecting materials correctly and use them properly. 
2. Students' comprehensive quality, innovation capacity is enhanced. As the college students technological innovation project, the preparation of high volume fly ash concrete, mainly focus on the changing rules fly ash replacement of $40 \%$ to $60 \%$ high volume fly ash concrete, to get excellent performance, affordable mixing ratio and provide reference base for high volume fly ash concrete application in the region.

\section{REFERENCES}

[1] Monchau, Jean Pierre, et al. "Infrared Emissivity Measurements of Building and Civil Engineering Materials: A New Device for Measuring Emissivity." International Journal of Thermophysics 35.9-10(2014):1817-1831

[2] Jin N G, Qian K L, Meng T. Study on Setting Experimental Teaching Independently in Civil Engineering Materials Course[J]. Research \& Exploration in Laboratory, 2009.

[3] Zeng Z, Shen Y, Chen F, et al. Exploration and Pracitce of Opening of Civil Engineering Materials Laboratory in Local College[J]. China Education Innovation Herald, 2013.
[4] Zou C X. On exploration for teaching reform for experiments for civil engineering materials[J]. Shanxi Architecture, 2012.

[5] Wen X D, Che J R, Yin S H, et al. Reform on Experiment Teaching in Civil Engineering Materials Course Based on Outstanding Engineers Training Program[J]. Journal of Ningbo University of Technology, 2014.

[6] Wang C. Thinking and practice on informatization teaching of civil engineering materials course[J]. Journal of Architectural Education in Institutions of Higher Learning, 2013.

[7] $\mathrm{Xu} \mathrm{H}$. Greening of Civil Engineering Materials[J]. Applied Mechanics \& Materials, 2014, 584-586:1768-1770.

[8] Vitton S J. Dynamic Testing of Civil Engineering Materials Using the Split-Hopkinson Pressure Bar[C]// Transportation Research Board 92nd Annual Meeting. 2013.

[9] Huang X. Mechanism Study on Engineering Properties of Concrete of Civil Engineering Materials[J]. Value Engineering, 2011.

[10] Lu J C. Application research on "the timely teaching method" in the teaching of Civil Engineering Materials[J]. China Construction Education, 2012.

[11] Yan C Y, Jian-Jun Y E. Civil Engineering Materials: Teaching Methods[J]. Journal of Xiangfan University, 2011.

[12] Zhao L. The Development of Work-integrated Learning Teaching Material Development:To Take Civil Engineering Materials Testing and Inspection as an Example[J]. Journal of Wuxi Institute of Technology, 2011. 